\section{穴 Heighten Science \\ P U B L I C I T I O N S Corporation ISSN 2576-3768}

\title{
Agricultural Residues for Future Energy Option in Sudan: An Analysis
}

\author{
Abdeen Mustafa Omer* \\ Energy Research Institute (ERI), The University of Nottingham, University Park, Nottingham NG7 \\ 2RD, Nottinghamshire, UK
}

\begin{abstract}
*Address for Correspondence: Abdeen Mustafa Omer, Energy Research Institute (ERI), The University of Nottingham, University Park, Nottingham NG7 2RD, Nottinghamshire, UK, Email: abdeenomer2@yahoo.co.uk

Submitted: 23 June 2018

Approved: 12 July 2018

Published: 13 July 2018

Copyright: () 2018 Omer AM. This is an open access article distributed under the Creative Commons Attribution License, which permits unrestricted use, distribution, and reproduction in any medium, provided the original work is properly cited
\end{abstract}

Keywords: Biomass resources; Wastes; Woodfuel; Biofuels; Energy; Environment; Sustainable development; Surfactant sciences

Check for updates

\section{Abstract}

Like many tropical countries, Sudan has ample biomass resources that can be efficiently exploited in a manner that is both profitable and sustainable. Fuel-wood farming offers costeffective and environmentally friendly energy solutions for Sudan, with the added benefit of providing sustainable livelihoods in rural areas. This article provides an overview of biomass energy activities and highlights future plans concerning optimum technical and economical utilization of biomass energy available in Sudan. Results suggest that biomass energy technologies must be encouraged, promoted, implemented, and fully demonstrated in Sudan.

\section{Introduction}

Biomass energy includes fuelwood, agricultural residues, animal wastes, charcoal and other fuels derived from biological sources. It is currently accounts for about $14 \%$ of world energy consumption. Biomass is the main source of energy for many developed and developing countries. In Sudan energy wood is available in the form of forest chips, fuelwood, wood waste, wood pellets and it is also produced to a very limited extent from willow crops in short rotation forestry. The major part of wood harvested in the forest area approximately 108 million hectares ends up as energy wood directly or indirectly after having been used for other purposes first. In 2000, the biomass share of the total energy consumption of the country is $87 \%$. The possibilities of increasing fuelwood production through afforestation programmes and substitution for commercial fuels are discussed. Biogas utilization in the rural regions is also reviewed, emphasaising its possible contribution.

Biomass refers to solid carbonaceous material derived from plants and animals. These include the residues of agriculture and forestry, animal waste and wastes from food processing operations. In the process of photosynthesis, a small amount of solar is used by plants and this trapped energy can be used in various ways. Wood and grass can be dried and then burnt to release heat. Plant material particularly rich in starches and sugars such as sugarcane and wheat can be fermented to produce ethanol. Alternately, methanol, which can be produced by the distillation of biomass, contains considerable cellulose such as wood and bagasse (residue from sugarcane). Both of these alcohols can be used the fuel vehicles and machinery, and can be mixed with petrol to make a petrol/alcohol blend.

Although biomass energy use is predominantly in rural areas, it also provides an important fuel source for the urban poor and many rural, small and medium scale industries. In order to meet the growing demand for energy, it is imperative to focus 
on efficient production and uses of biomass energy to requirements (such as electricity and liquid fuels). This production of biomass in all its forms for fuel, food and fodder demands environmentally sustainable land use and integrated planning approaches [1].

\section{Methodology}

This study highlights the energy problem and the possible saving that can be achieved through the use of biomass sources energy. Also, this study clarifies the background of the study, highlights the potential energy saving that could be achieved through use of biomass energy source and describes the objectives, approach and scope of the theme.

The aim of any modern biomass energy systems must be:

- To maximise yields with minimum inputs.

- Utilisation and selection of adequate plant materials and processes.

- Optimum use of land, water, and fertiliser.

- Create an adequate infrastructure and strong $\mathrm{R}$ and $\mathrm{D}$ base.

In compiling energy consumption data one can categorise usage according to a number of different schemes:

- Traditional sector- industrial, transportation, etc.

- $\quad$ End-use- space heating, process steam, etc.

- $\quad$ Final demand- total energy consumption related to automobiles, to food, etc.

- Energy source- oil, coal, etc.

- Energy form at point of use- electric drive, low temperature heat, etc.

\section{Major energy consuming sectors}

Sudan is still considered as one of the 25 most developing African countries. Agriculture is the backbone of economic and social development in Sudan. About 80\% of the population depends on agriculture, and all other sectors are largely dependent on it. Agriculture contributes to about $41 \%$ of the gross national product (GNP) and $95 \%$ of all earnings [2]. Agriculture determines for the last 30 years the degree of performance growth of the national economy.

\section{Agriculture sector}

During the last decades agriculture contributed by about $41 \%$ to the Sudan GNP [3]. This share remained stable until 1984-1985 when Sudan was seriously hit by drought and desertification, which led to food shortages, deforestation, and also, by socioeconomic effects caused the imposed civil war. The result dropped the agriculture share to about $37 \%$. Recent development due rehabilitation and improvement in agricultural sector in 1994 has raised the share to $41 \%$. This share was reflected in providing raw materials to local industries and an increased export earning besides raising percentage of employment among population. This sector consumed $2.5 \%$ of the total energy consumption ( $28 \%$ from electricity, $14.8 \%$ from fossil fuels, and the rest from biomass fuels) [4].

\section{Industrial sector}

The industrial sector is mainly suffering from power shortages, which is the prime mover to the large, medium and small industries. The industrial sector was consuming $5.7 \%$ of the total energy consumption, distributed as follows: $55 \%$ from petroleum products, $13 \%$ from biomass and $32 \%$ from electricity [5]. 


\section{Domestic use}

Household is the major energy consumer. It consumed $92 \%$ of the total biomass consumption in form of firewood and charcoal. From electricity this sector consumed $60 \%$ of the total consumption, and $5.5 \%$ of petroleum products [6].

\section{Transport sector}

The transportation sector (railways, ships, boats, etc.) was not being efficient for the last two decades because of serious damage happened to its infrastructure (roads, workshops, and maintenance centres, etc.). It consumed $10 \%$ of the total energy consumption and utilized $60 \%$ of the total petroleum products supplied [7].

\section{Biomass resources}

Agriculture is the source of a considerable sum of hard currency that is needed for the control of balance of payment in the country's budget, as well as it is the major source of raw materials for local industry. Biomass resources play a significant role in energy supply in Sudan as in all other developing countries. Biomass resources should be divided into residues or dedicated resources, the latter including firewood and charcoal from forest resources as shown in Table 1.

Approximately $13.8 \times 10^{6} \mathrm{~m}^{3}$ of biomass are consumed per year as shown in Table 2. To avoid resource depletion, Sudan is currently undergoing a reforestation program of $1.05 \times 10^{6}$ hectares. Biomass residues are more economically exploitable and more environmentally benign than dedicated biomass resources [8]. There exists a variety of readily available sources in Sudan, including agricultural residues such as sugar cane bagasse, and molasses, cotton stalks, groundnut shells, tree/forest residues, aquatic weeds, and various animal wastes as shown in Table 2 .

Direct burning of fuel-wood and crop residues constitute the main usage of Sudan biomass, as is the case with many developing countries. However, the direct burning of biomass in an inefficient manner causes economic loss and adversely affects human health. In order to address the problem of inefficiency, research centres around the country are investigating the viability of converting the resource to a more useful form, namely solid briquettes and fuel gas. Briquetting is the formation of a char (an energydense solid fuel source) from otherwise wasted agricultural and forestry residues. One of the disadvantages of wood fuel is that it is bulky and therefore requires the transportation of large volumes. Briquette formation allows for a more energy-dense fuel to be delivered, thus reducing the transportation cost and making the resource more competitive. It also adds some uniformity, which makes the fuel more compatible with systems that are sensitive to the specific fuel input [9].

Table 1: Annual biomass energy sources available in Sudan ( $10^{6}$ tonnes) [3].

\begin{tabular}{|c|c|}
\hline Source & Volume of biomass (10 ${ }^{6}$ tonnes) \\
\hline Natural and cultivated forestry & 2.9 \\
\hline Agricultural residues & 5.2 \\
\hline Animal wastes & 1.1 \\
\hline Water hyacinth and aquatic weeds & 3.2 \\
\hline Total & 13.4 \\
\hline
\end{tabular}

Table 2: Annual biomass energy consumption pattern in Sudan $\left(10^{3} \mathrm{~m}^{3}\right)$ [3].

\begin{tabular}{|c|c|c|c|c|}
\hline Sector & Firewood & Charcoal & Total & Percent (\%) \\
\hline Residential & 6148 & 6071 & 12219 & $88.5 \%$ \\
\hline Industrial & 1050 & 12 & 1062 & $7.7 \%$ \\
\hline Commercial & 32 & 284 & 316 & $2.3 \%$ \\
\hline Quranic schools & 209 & 0 & 209 & $1.5 \%$ \\
\hline Total & 7439 & 6367 & 13806 & \\
\hline Percent (\%) & $54 \%$ & $46 \%$ & & $100.0 \%$ \\
\hline
\end{tabular}


Briquetting of agricultural residues in Sudan started in 1980, with a small briquetting plant using groundnut shells in Khartoum. The second plant was introduced in Kordofan (Western Sudan) with a capacity of 2 tonnes per hour with maximum 2000 tonnes per season. Another prototype unit was brought, and worked in Nyala with capacity of 0.5 tonnes per hour (i.e., 600 tonnes per season). In central Sudan, a briquetting plant of cotton stalks was installed at Wad El Shafie with a capacity of 2 tonnes per hour (i.e., 2000 tonnes per season). The ongoing project in New Halfa is constructed to produce 1200 tonnes per season of bagasse briquettes [10]. A number of factories have been built for carbonisation of agricultural residues, namely cotton stalks [11]. The products are now commercialised. More than 2000 families have been trained to produce their cooking charcoal from the cotton stalks.

In Sudan, most urban households burn charcoal on traditional square "Canun" stoves that have very low fuel-to-heat conversion efficiencies. The following prototypes were all tried and tested in Sudan:

- The metal clad Kenyan Jiko

- The vermiculite lined traditional Kenyan Jiko

- The all-ceramic Jiko in square metal box

- $\quad$ The open draft Dugga stoves

- The controlled draft Dugga stoves

- The Umeme Jiko "Canun Al Jadeed"

Local traditional stoves were tested, improved, invested, and commercially used in Sudan [12]. Traditional muddy stoves, Bucket stoves and Tin stoves.

Another area in which rural energy availability could be secured where woody fuels have become scarce, are the improvements of traditional cookers and ovens to raise the efficiency of fuel saving. Also, by planting fast growing trees to provide a constant fuel supply. The energy development is essential and economically important since it will eventually lead to better standards of living, people's settlement, and selfsufficient in the following:

- $\quad$ Food and water supplies.

- $\quad$ Better services in education and health care.

- $\quad$ Good communication modes.

The aim of any modern biomass energy systems must be:

- To maximise yields with minimum inputs.

- Utilisation and selection of adequate plant materials and processes.

- Optimum use of land, water, and fertiliser.

- Create an adequate infrastructure and strong R \& D base.

Gasification is based on the formation of a fuel gas (mostly $\mathrm{CO}$ and $\mathrm{H}_{2}$ ) by partially oxidising raw solid fuel at high temperatures in the presence of steam. The technology, initially developed for use with charcoal as fuel input, can also make use of wood chips, groundnut shells, sugar cane bagasse, and other similar fuels to generate capacities from 3 to $100 \mathrm{~kW}$ for biomass systems. Three gasifier designs have been developed to make use of the diversity of fuel inputs and to meet the requirements of the product gas output (degree of cleanliness, composition, heating value, etc.) [13]. 
Furthermore, Sudan is investigating the potential to make use of more and more of its waste. Household waste, vegetable market waste, and waste from the cotton stalks, leather, pulp, and paper industries can be used to produce useful energy either by direct incineration, gasification, digestion (biogas production), fermentation, or cogeneration.

The use of biomass through direct combustion has long been, and still is the most common mode of biomass utilisation as shown in Tables 3-5). Examples for dry (thermo-chemical) conversion processes are charcoal making from wood (slow pyrolysis), gasification of forest and agricultural residues (fast pyrolysis), and of course, direct combustion in stoves, furnaces, etc. Wet processes require substantial amount of water to be mixed with the biomass.

\section{Biogas}

At present, Sudan uses a significant amount of kerosene, diesel, firewood, and charcoal for cooking in many rural areas. Biogas technology was introduced to Sudan in mid-seventies when GTZ designed a unit as a side-work of a project for water hyacinth control in central Sudan. Anaerobic digesters producing biogas (methane) offer a sustainable alternative fuel for cooking that is appropriate and economic in rural areas. In Sudan, there are currently over 200 installed biogas units, covering a wide range of

\begin{tabular}{|c|c|}
\hline \multicolumn{2}{|c|}{ Table 3: Biomass residues, current use and general availability [14]. } \\
\hline $\begin{array}{c}\text { Type of residue } \\
\text { Wood industry waste }\end{array}$ & Current use / availability \\
\hline Vegetable crop residues & No residues available \\
\hline Food processing residue & Energy needs \\
\hline Sorghum, millet, wheat residues & Fodder, and building materials \\
\hline Groundnut shells & Fodder, brick making, direct fining oil mills \\
\hline Cotton stalks & Domestic fuel considerable amounts available for short period \\
\hline Sugar, bagasse, molasses & Fodder, energy need, ethanol production (surplus available) \\
\hline Manure & Fertilizer, brick making, plastering (Zibala) \\
\hline
\end{tabular}

\begin{tabular}{|c|c|c|}
\hline Subject & Tools & Constraints \\
\hline $\begin{array}{l}\text { Utilization and land clearance for agriculture } \\
\text { expansion }\end{array}$ & $\begin{array}{ll}\text { - } & \text { Stumpage fees } \\
\text { - } & \text { Control } \\
\text { - } & \text { Extension } \\
\text { - } & \text { Conversion } \\
\text { - } & \text { Technology }\end{array}$ & $\begin{array}{ll}\text { - } & \text { Policy } \\
\text { - } & \text { Fuel-wood planning } \\
\text { - } & \text { Lack of extension } \\
\text { - } & \text { Institutional }\end{array}$ \\
\hline Utilization of agricultural residues & $\begin{array}{ll}\text { - } & \text { Briquetting } \\
\text { - } & \text { Carbonisation } \\
\text { - } & \text { Carbonisation and } \\
\text { - } & \text { briquetting } \\
\text { - } & \text { Fermentation } \\
\text { - } & \text { Gasification }\end{array}$ & $\begin{array}{ll}\text { - } & \text { Capital } \\
\text { - } & \text { Pricing } \\
\text { - } & \text { Policy and } \\
\text { - } & \text { legislation } \\
\text { - } & \text { Social acceptability }\end{array}$ \\
\hline
\end{tabular}

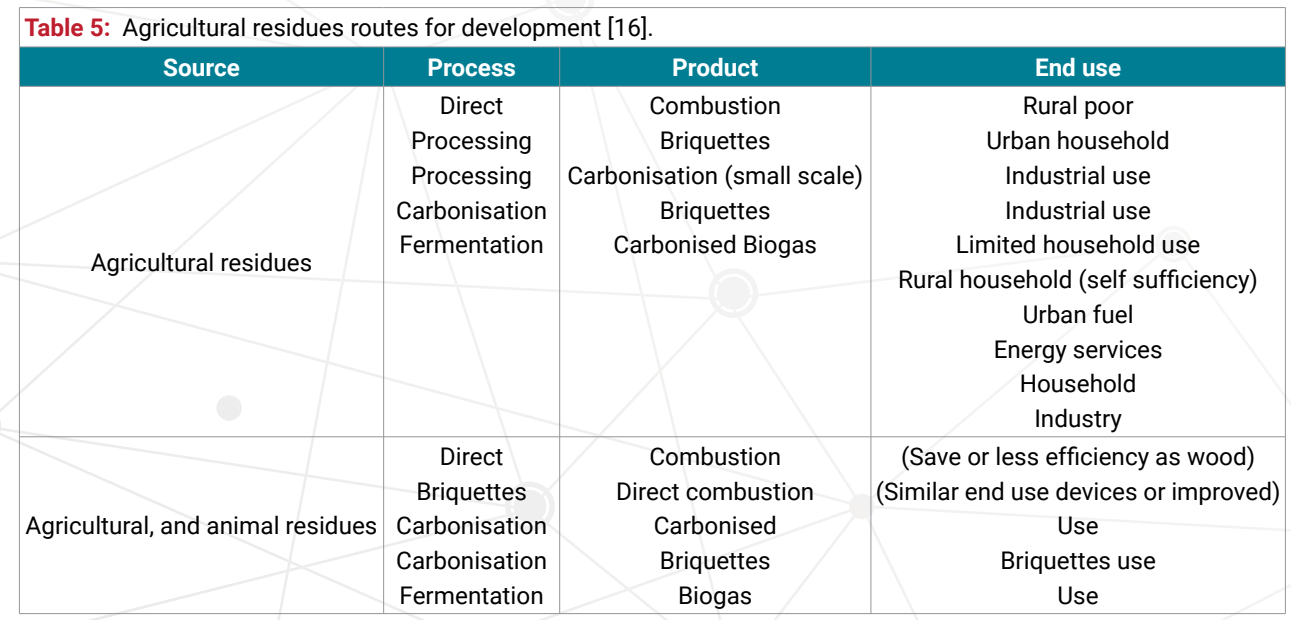


scales appropriate to family, community, or industrial uses. The agricultural residues and animal wastes are the main sources of feedstock for larger scale biogas plants.

There are in practice two main types of biogas plant that have been developed in Sudan: the fixed dome digester, which is commonly called the Chinese digester (120 units each with volumes 7-15 $\mathrm{m}^{3}$ ). The other type is with floating gasholder known as Indian digester ( 80 units each with volumes $5-10 \mathrm{~m}^{3}$ ). The solid waste from biogas plants adds economic value by providing valuable fertilizer as by products [17].

Biogas technology can not only provide fuel, but also important for comprehensive utilization of biomass forestry, animal husbandry, fishery, evolutions the agricultural economy, protecting the environment, realizing agricultural recycling, as well as improving the sanitary conditions, in rural areas. The introduction of biogas technology on wide scale has implications for macro planning such as the allocation of government investment and effects on the balance of payments. Factors that determine the rate of acceptance of biogas plants, such as credit facilities and technical backup services, are likely to have to be planned as part of general macro-policy, as do the allocation of research and development funds $[18,19]$.

\section{Sugarcane biomass}

Residuals from the sugar cane industry represent by far the most important source of current and potential biomass resources in Sudan. The sugar industry in Sudan goes back fifty years. Sugar cane plantations cover one-fifth of the arable land in Sudan. In addition, to raw sugar, Sudan enterprises produce and utilize many valuable cane co-products for feed, food, energy and fibre. At present, there are 5 sugar factories as illustrated in Table 6.

Sugarcane bagasse and sugar cane trash already provide a significant amount of biomass for electricity production, but the potential is much higher with advanced cogeneration technologies. Most sugar factories in Sudan, as elsewhere in the developing world, can produce about 15-30 kWh per tonne of cane. If all factories were fitted with biomass gasifier-combined cycle systems, $400-800 \mathrm{kWh}$ of electricity could be produced per tonne of cane, enough to satisfy all of Sudan's current electricity demand. Some of the sugar plants are near electric grids (Kenana, El Genaid and Sennar) and others have their own grids.

In Sudan there have been no alcohol distilleries since 1983. The three factories were closed due to Islamic Laws. The current circumstances suggest that Sudan should consider expanding production for use as transportation fuel, but this option has not yet been pursued. The alcohol is used for a variety of applications, mainly for medical purposes and rum production.

\section{Role of biomass energy}

Biomass is generally and erroneously regarded as a low status fuel and rarely finds its way into the energy statistics when, in fact, it should be considered as a renewable energy equivalent to fossil fuels. It offers considerable flexibility of fuel supply due to the range and diversity of fuels that can be produced. Biomass can be burnt directly or it can be converted into solid, gaseous and liquid fuels using conversion technologies

\begin{tabular}{|c|c|c|}
\hline Factory & Design capacity & Yearly bagasse \\
\hline Kenana & 300 & 266 \\
\hline El Genaid & 60 & 53 \\
\hline New Halfa & 75 & 65 \\
\hline Sennar & 100 & 58 \\
\hline Asalaia & 100 & 60 \\
\hline Total & 635 & 502 \\
\hline
\end{tabular}


such as fermentation to produce alcohols, bacterial digestion to produce biogas and gasification to produce a natural gasification to produce a natural gas substitute. Industrial, agricultural livestock and forest residues can be used as a biomass energy source, or energy crops such as trees and sugarcane can be grown specifically for conversion to energy. Projections of final biomass energy consumption by region are given in Table 7. Total final consumption of biomass in developing countries is projected to continue to increase, rising from $825 \times 10^{6}$ tonnes of oil equivalent (Mtoe) in 1995 to $1071 \times 10^{6}$ Mtoe in 2020, although at a lower rate than population growth and a much lower rate than conventional energy use. The rate of growth of total biomass consumption is relatively low and is slowing down: it is projected to be $1.2 \%$ per annum between 1995 and 2020,1.1\% between 2000 and 2010 and 1\% between 2010 and 2020. During the same periods, final consumption of conventional fuels is projected to grow at much faster rates $(4.3,3.5$ and $3.1 \%$ per annum respectively). As a result, the share of biomass in total final consumption will decline from 34\% in 1995 to $22 \%$ in 2020 . There are significant regional differences in the rates of growth and resulting shares, as given in Table 7 .

Among the renewable energy sources, biomass seems one of the most interesting because of its share of the total energy consumption of Sudan is high at $87 \%$, and the techniques for converting it to useful energy are not necessarily sophisticated. Implementation of biomass-based energy programmes will not, of course, be a definitive solution to the country's energy problem, but it will bring new insight for efficient energy use in the household sector, especially in rural areas where more than $70 \%$ of the population lives ( 25 million). The estimates are based in the recoverable energy potential from the main agricultural residues, livestock farming wastes, forestry and wood processing residues, and municipal wastes.

Fuelwood, animal wastes, agricultural crop residues, and logging wastes have been used through direct burning in Sudan for many years. These sources are often called non-commercial energy sources, but in Sudan fuelwood is a tradable commodity since it is the primary fuel of rural areas and the urban poor section. Traditional fuels predominate in rural areas; almost all biomass energy is consumed in the household sector for heating, cleaning and cooking needs of rural people. Especially in the villages

\begin{tabular}{|c|c|c|c|c|}
\hline \multirow[b]{2}{*}{ Region } & \multicolumn{4}{|c|}{1995} \\
\hline & Biomass & Conventional Energy & Total & Share of Biomass (\%) \\
\hline Africa & 205 & 136 & 341 & 60 \\
\hline China & 206 & 649 & 855 & 24 \\
\hline East Asia & 106 & 316 & 422 & 25 \\
\hline Latin America & 73 & 342 & 416 & 18 \\
\hline South Asia & 235 & 188 & 423 & 56 \\
\hline Total developing countries & 825 & 1632 & 2456 & 34 \\
\hline Other non-OECD countries & 24 & 1037 & 1061 & 1 \\
\hline Total non-OECD countries & 849 & 2669 & 3518 & 24 \\
\hline OECD countries & 81 & 3044 & 3125 & 3 \\
\hline \multirow[t]{2}{*}{ World } & 930 & 5713 & 6643 & 14 \\
\hline & \multicolumn{4}{|c|}{2020} \\
\hline Region & Biomass & Conventional Energy & Total & Share of Biomass (\%) \\
\hline Africa & 371 & 266 & 631 & 59 \\
\hline China & 224 & 1524 & 1748 & 13 \\
\hline East Asia & 118 & 813 & 931 & 13 \\
\hline Latin America & 81 & 706 & 787 & 10 \\
\hline South Asia & 276 & 523 & 799 & 35 \\
\hline Total developing countries & 1071 & 3825 & 4896 & 22 \\
\hline Other non-OECD countries & 26 & 1669 & 1695 & 1 \\
\hline Total non-OECD countries & 1097 & 5494 & 6591 & 17 \\
\hline OECD countries & 96 & 3872 & 3968 & 2 \\
\hline World & 1193 & 9365 & 10558 & 11 \\
\hline
\end{tabular}


(households on the high plateau) the preparation of three stone fires is very attractive to the villagers. In this method, food and plant residues are put in a large boiler with water and cooked on a traditional stove at the outside the house for animal feed, because cooked food and plant residues are cheaper than flour and bran. Nevertheless, this method consumes much more fuelwood than the cooking on the stoves method. On the other hand, wood is the most practical fuel for serving a large number of people because the size of the batch of food is only limited by the volume of the pot and not by the size of the stove's burner. Fuelwood is also convenient for cooking of the meal of meat as a cutlet meatball and meat roasted on a revolving vertical spit.

Special attention should therefore be given to reviewing forest resources, plantation programmes and the possibilities of substitution of fuelwood for commercial fuels or for other fuels such as biogas. The main sources of fuelwood supply in the country can be broadly be grouped into two main categories, i.e., forest sources (forests under the control of forest departments) and non-forest sources (private farmland and wild lands). Women, assisted by children almost always, perform the gathering of fuelwood in rural areas of developing countries. As fuelwood becomes scarce, which is the case in many parts of the world, the collection time has increased and although men do not perceive it, this has many undesirable consequences, which can be clearly seen in many rural region of Sudan. Women have less time for their other important functions, such as cooking, washing, water collection, and child rearing which may affect the nutrition and health of the entire family. Wood energy is, for many countries, one of the few locally available sources of energy, which they can afford. Its substitution by imported fossil fuels, as has often been carelessly recommended, should attentively be evaluated to avoid undesirable political, economic and social consequences.

\section{Bioenergy potential}

For efficient use of Bioenergy resources, it is essential to take account of the intrinsic energy potential. Despite the availability of basic statistics, many differences have been observed between the previous assessments of Bioenergy potential [22-24]. These were probably due to different assumptions or incomplete estimations of the availability, accessibility and use of by products. The biomass sources have been used through:

- Anaerobic digestion of municipal wastes and sewage.

- Direct combustion of forestry and wood processing residues.

- Direct combustion in the case of main dry crop residues.

- Anaerobic digestion of moist residues of agricultural crops and animal wastes.

Wood is very important raw material used by a number of industries. Its excessive utilization as a fuel results in soil erosion, degradation of the land, reduced agricultural productivity and potentially serious ecological damage. Hence, minimization of fuelwood demand and a national level and the increment an increase in the efficiency of fuelwood use seems to be essential. Utilization of more efficient stoves and improvement of insulation using locally available materials in buildings are also effective measures to increase efficiency. Biogas or commercial fuels may be thought of as possible substitutes for fuelwood. In rural areas of Sudan (Table 8), liquefied petroleum gases (LPG) are a strong candidate to replace firewood. Indeed, increased, LPG utilization over the last decade has been one of the main reasons has lead to the deceleration of the diffusion of biogas technology into rural areas.

Biomass gasification is a technology that transforms solid biomass into syngas (hydrogen and carbon monoxide mixtures produced from carbonaceous fuel). Current use of biomass, which stands at about $87 \%$ of the total energy supply in Sudan, is 


\begin{tabular}{|c|c|c|}
\hline Energy carrier & Energy end-use & Typical annual household consumption \\
\hline Fuel-wood & $\begin{array}{c}\text { Cooking } \\
\text { Water heating } \\
\text { Building materials } \\
\text { Animal fodder preparation }\end{array}$ & 10 tonnes \\
\hline Kerosene & $\begin{array}{c}\text { Lighting } \\
\text { Ignition fires }\end{array}$ & 100 litres \\
\hline Dry cell batteries & $\begin{array}{c}\text { Lighting } \\
\text { Small appliances }\end{array}$ & 50 pairs \\
\hline Animal power & $\begin{array}{l}\text { Transport } \\
\text { Land preparation for farming } \\
\text { Food preparation (threshing) }\end{array}$ & \\
\hline Human power & $\begin{array}{l}\text { Transport } \\
\text { Land preparation for farming } \\
\text { Food preparation (threshing) }\end{array}$ & \\
\hline
\end{tabular}

primarily used in combustion for immediate use. Small-scale gasification for combined heat and power (CHP), also called embedded generation. Many villages and minigrids can be served by biomass power generation in the size range from $1 \mathrm{kWe}$ to 5 MWe. Biomass fuels are characterized by high and variable moisture content, low ash content, low density, and fibrous structure. In comparison with other fuels, they are regarded as of low quality despite low ash content and very low sulphur content.

Even though community digesters for a whole village appear to be economically more attractive, family type designs should also be studied. Moreover, detailed realistic economic and cost-benefit comparisons with other alternatives will help in determining the level of incentives that could be produced by the government for the construction of digesters. The energy possibilities of industrial and municipality wastes should be evaluated, especially in the big cities. Combined heat and power systems could be designed to make use of these wastes as fuel. The possibilities of using waste heat in district heating systems could be also of interest in industrial regions.

\section{Environmental issues of biomass}

Climate change is a growing concern around the world, and stakeholders are aggressively seeking energy sources and technologies that can mitigate the impact of global warming. This global concern is manifest in the 1997 Kyoto Protocol, which imposes an imperative on developed nations to identify feasible options by the next Conference of the Parties to the Convention (COP) meeting later in 2001. Possible actions range from basic increases in energy efficiency and conservation, to sophisticated methods of carbon sequestration to capture the most common greenhouse gases (GHGs) emission $\left(\mathrm{CO}_{2}\right)$. On the other hand, renewable energies have always been identified as a prime source of clean energies that emit little or no net GHGs into the atmosphere. Among the renewable energy sources, biomass is important for Sudan due to its share of the total energy production which at $87 \%$ is high and the techniques for converting it to useful energy are easy. Forest ecosystems cause effects on the balance of carbon mainly by the assimilation of $\mathrm{CO}_{2}$ by the aboveground biomass of the forest vegetation. The annual emissions of greenhouse gases from fossil fuel combustion and land use change are approximately $33 \times 10^{5}$ and $38 \times 10^{5}$ tonnes respectively. Vegetation and in particular forests, can be managed to sequester carbon. Management options have been identified to conserve and sequester up to $90 \mathrm{Pg} \mathrm{C}$ in the forest sector in the next century, through global afforestation $[25,26]$. This option may become a necessity (as recommended at the Framework Convention on Climate Change meeting held in Kyoto), but a preventative approach could be taken, reducing total GHGs emissions by substituting biomass for fossil fuels in electricity production.

Simply sequestering carbon in new forests is problematic because trees cease sequestering once they reach maturity, and as available land is used up the cost of 
further afforestation will grow. Indeed the cost of reducing the build-up of GHGs in the atmosphere is already lower for fossil fuel substitution than for sequestration, since fast growing energy crops are more efficient at carbon removal, and because revenue is generated by the scale of electricity. Some biomass fuel cycles can also provide the additional benefits of enhanced carbon storage. The relative merits of sequestration versus fossil fuel substitution are still debated. The flow of carbon during the life cycle of the biomass should determine whether it is better left standing, used as fuel or used as long-lived timber products. Where there are existing forests in good condition there is general agreement that they should not be cut for fuel and replanted. This principle also concurs with the guidelines for nature protection, i.e., energy crops should never displace land uses of high ecological value. Where afforestation is undertaken, however, fossil fuel substitution, both by using wood fuel and using timber as a renewable raw material, should be more sustainable and less costly approach than sequestration could also be used to displace the harvest of more ecologically valuable forests.

Air pollution is becoming a great environmental concern in Sudan because the primary energy consumption increased. Air pollution from energy utilization in the country is due to the combustion of petroleum, natural gas, wood, agricultural and animal wastes. The amounts of GHGs emissions are increasing quickly due to increasing energy consumption in the country (but lower than the other African countries).

\section{Economic incentives to protect the environment}

In Some countries, a wide range of economic incentives and other measures are already helping to protect the environment. These include:

- Taxes and user charges that reflect the costs of using the environment e.g., pollution taxes and waste disposal charges.

- Subsidies, credits and grants that encourage environmental protection.

- Deposit-refund systems that prevent pollution on resource misuse and promote product reuse or recycling.

- Financial enforcement incentives, e.g., fines for non-compliance with environmental regulations.

- Tradable permits for activities that harm the environment.

Even with modest assumptions about the availability of land, comprehensive fuelwood farming programmes offer significant energy, economic and environmental benefits. These benefits would be dispersed in rural areas where they are greatly needed and can serve as linkages for further rural economic development. The nations as a whole would benefit from savings in foreign exchange, improved energy security, and socio-economic improvements. With a nine-fold increase in forest-plantation cover, a nation's resource base would be greatly improved. The international community would benefit from pollution reduction, climate mitigation, and the increased trading opportunities that arise from new income sources.

\section{Mitigation measures}

Potential mitigation measures to decrease greenhouse gas (GHG) emissions from the oil industry and decelerate the threat of global climate change may include the following:

- Controlling GHGs emissions by improving the efficiency of energy use, changing equipment and operating procedures.

- Controlling GHGs emission detection techniques in oil production, transportation and refining processes in Sudan. 
- More efficient use of energy-intensive materials and changes in consumption patterns.

- A shift to low carbon fuels, especially in designing new refineries.

- The development of alternative energy sources (e.g., biomass, solar, wind, hydro-electrical and cogeneration).

- The development of effective environment standards, policies, laws and regulations particularly in the field of oil industry.

- Activating and supporting environmental and pollution control activities within the Ministry of Energy and Mining (MEM) to effectively cope with the evolving oil industry in Sudan.

\section{Barriers to implementation}

The afforestation program appears an attractive option for the country to pursue in order to reduce the level of atmospheric carbon by enhancing carbon sequestration in the nation's forests, which would consequently mitigate climate change. However, it is acknowledged that certain barriers need to be overcome if the objectives were to be fully achieved. These include the following:

- Low level of public awareness of the economic/environmental benefits of forestry.

- The generally low levels of individual income.

- Pressures from population growth.

- The land tenural system, which makes it difficult (if not possible) for individuals to own or establish forest plantations.

- Poor pricing of forest products especially in the local market.

- Inadequate financial support on the part of governments.

- Weak institutional capabilities of the various Forestry Departments as regards technical manpower to effectively manage tree plantations.

\section{Biomass and sustainability}

There is an unmistakable link between energy and sustainable human development. Energy is not an end in itself, but an essential tool to facilitate social and economic activities. Thus, the lack of available energy services correlates closely with many challenges of sustainable development, such as poverty alleviation, the advancement of women, protection of the environment, and jobs creation. Emphasis on institutionbuilding and enhanced policy dialogue is necessary to create the social, economic, and politically enabling conditions for a transition to a more sustainable future. On the other hand, biomass energy technologies are a promising option, with a potentially large impact for Sudan as with other developing countries, where the current levels of energy services are low. Biomass accounts for about one third of all energy in developing countries as a whole, and nearly $96 \%$ in some of least developed countries.

The convention on Biological Diversity set conservation of biodiversity on the world agenda. Gaps in knowledge need to be addressed for actions to be effective and sustainable. Gaps include: species diversity, microorganisms and their ecological roles, ecological and geographical status of species, human capacity to access and forecast bio-ecological degradation. Requirements for global inventories call for worldwide collaboration. Criteria for setting priorities need to be formulated and agreed. Global 
inventorying needs a collaborative international effort, perhaps under the aegis of the Convention on Biological Diversity. The recently formulated global taxonomy initiatives are a step in the right direction.

\section{Climate change}

The debate over an international climate change regime has thus far focused primarily on efficiency concerns in developed countries. In the international negotiations over the control of climate change, the developing countries so far have assumed few obligations. In the Kyoto Protocol on limiting greenhouse gas (GHG) emissions, only a subset of the world's economies. At present, this debate has not progressed very far. There are several reasons for this impasse. First, there is a distinction between cost effectiveness (where in the world should the control be undertaken in order to minimize the global costs of control) and equity (who should bear the costs of mitigation and abatement resulting from climate change) that has not been adequately clarified and agreed upon by the parties to the Protocol. Second, the global control or anthropogenic climate change will require complex cooperative efforts among a large number of individual nations. This cooperative effort will have to be based on a thorough understanding of how the various participating nations contribute to the process of global climate change, and how that process affects them. One of the fundamental principles of environmental policy is that the polluter pays for using the environment and the use of natural resources. This is one way of imposing responsibility for environmental consequences on the party causing the environmental damage. In the context of environmental taxes, it is the polluter who pays, which is one reason why taxes are so suitable as an instrument for environmental policy. With respect to the causes of global warming, and the obligations, which were adopted at the Kyoto Conference, it is useful to examine the possible role of such economic instruments.

\section{Distribution of potential sources of energy}

Hydropower supplied 55 per cent of electricity. The remaining 45 per cent of electricity was produced from imported thermal energy. Total electricity consumption in 2002 was $640 \times 10^{3} \mathrm{MWh}$ [27], representing per capita consumption of 53 (kWh/ year). It is estimated that total energy consumption will increase by 30 per cent over the next decade, and electricity demand by 70 per cent. Sudan's installed capacity is $640 \mathrm{MW}$ only from hydropower, of which about $520 \mathrm{MW}$ on the grid is available due to losses in transmission and problems at the dams (Figure 1).

The organic carbon content of soils in Sub-Saharan Africa tends to be low due to the high temperatures, low clay contents (or action exchange capacity) and low organic inputs due to poor crop nutrition. However, increasing the organic inputs, increases the steady state carbon content, and so sequesters soil carbon. If organic inputs were increased, for instance by adding material from a biogas digester to the soil, the carbon content of the soil would increase until it reached a new steady state level; after that no more carbon would be sequestered unless the organic inputs were further increased. The sequestered carbon is not a permanent store; it will only remain in the soil while the balance between the organic inputs and the rate of decomposition remains

\begin{tabular}{ll}
\hline Figure 1: Electricity generated in $2005(\mathrm{GWh})$. & $\begin{array}{l}\text { Hydro } \\
\text { Stem } \\
\text { Note: Data from 2013. }\end{array}$ \\
\hline
\end{tabular}


the same [5]. If the organic inputs were reduced to their original level, for instance because the material from the biogas digester was no longer available, the amount of carbon held in the soil would return to its original level. Furthermore, if the rate of decomposition increased, for instance due to increased temperatures associated with climate change, the amount of carbon held in the soil would also decrease. The rate of decomposition of material added to the soil also depends on the quality of the organic matter. If sufficient nutrients are available to allow decomposition, fresh material tends to decompose more quickly than material that has been composted or digested. Composted and digested material decomposes more quickly than material that has been converted to charcoal, which is highly recalcitrant [28].

In a country with a population dense, there are extreme pressures on energy and waste systems, which can stunt the country's economic growth. However, Sudan has recognized the potential to alleviate some of these problems by promoting renewable energy and utilizing its vast and diverse climate, landscape, and resources, and by coupling its solutions for waste disposal with its solutions for energy production. Thus, Sudan may stand at the forefront of the global renewable energy community, and presents an example of how non-conventional energy strategies may be implemented.

\section{Discussions}

Development of sustainable energy systems based on renewable biomass feedstocks is now a global effort. Lignocellulosic biomass contains polymers of cellulose, hemicellulose, and lignin, bound together in a complex structure. Liquid biofuels, such as ethanol, can be made from biomass via fermentation of sugars derived from the cellulose and hemicellulose within Lignocellulosic materials, but the biomass must be subjected to pretreatment processes to liberate the sugars needed for fermentation. Production of value-added co-products along-side biofuels through integrated biorefinery processes creates the need for selectivity during pretreatment. This paper presents a survey of biomass pretreatment technologies with emphasis on concepts, mechanism of action and practicability [29].

The industrial-scale production of Lignocellulosic-based biofuels from biomass is expected to benefit society and the environment. The main pathways of residues processing include advanced hydrolysis and fermentation, pyrolysis, gasification, chemical synthesis and biological processes. The products of such treatment are second generation biofuels. The degree of fermentation of organic substances depends primarily on their composition and chemical structure. Optimization of fermentation conditions leads to better understanding of occurring processes. Therefore, an overview of recent developments in fermentation modeling is necessary to establish process parameters enabling high yields of biofuels production. Among process parameters affecting the yield and rate of biogas and biohydrogen, $\mathrm{pH}$ of the pulp, temperature, composition, biomass pre-treatment and digestion time are to be considered. The technology of anaerobic co-digestion has been intensively developed as a valuable solution for the disposal of organic wastes and sewage sludge. Modeling of biogas production from Lignocellulosic biomass has been intensively investigated and is well described by adapted ADM1 model. Modeling of fermentative hydrogen production lacks a kinetic model incorporating process parameters with the view of pretreatment and fermentation. This paper presents the state-of-the-art on the problems related to Lignocellulosic biomass pre-treatment and discusses the mechanisms of lignocellulosics conversion to gaseous biofuels [30].

Several factors must be taken into account regarding the choice for biomass pretreatment regarding the most advantageous use of the biomass solid and liquid streams resulting from the subsequent enzymatic hydrolysis step. The resulting sugar syrups stream and the lignin stream, as either a solid or a liquid form must be carefully considered for the deployment of a fully integrated biorefinery, for the use of biomass as a source of fuels and chemicals in a sustainable an environmentally friendly way [31]. 


\section{Conclusion}

Sudan is an energy importing country and the energy requirements has been supplied through imports that have caused financial problems. Because of the economical problems in Sudan today, the Sudanese energy policy should be concentrated on assurance of energy supply, reliability, domestic sufficiency, in time, in economic terms, and renewability. Therefore as a renewable energy source, biomass (especially fuelwood) seems interesting because its share of the total energy production at $87 \%$ is high and the techniques for converting it to useful energy are easy. On the other hand, biomass may, however, see greatly expanded use in response to the environmental problems caused by fossil fuel use in the country. Biomass has been proposed to have a central role to play in future, more sustainable energy scenarios. For this to become a reality several real problems need to be overcome. In Sudan as in other developing countries modernization of biomass energy provision is an urgent necessity for the sake of human health, protection of the environment, and climate change abatement. Given sufficient recognition, resources and research biomass could become the environmentally friendly fuel of the future.

\section{(Appendix \& Annex)}

\section{References}

1. Galal MY. The Gezira Scheme-the greatest on the earth-under one management. Khartoum: Sudan. 1997.

2. Robinson G. Changes in construction waste management. Waste Management World. 2007; 43-49.

3. Abdeen MO. Development of integrated bioenergy for improvement of quality of life of poor people in developing countries. In F. L. Magnusson \& O. W. Bengtsson (Eds.), Energy in Europe: Economics, policy and strategy. New York, NY: NOVA Science Publishers. 2009; 341-373.

4. Omer AM. Green energies and environment. Renewable and Sustainable Energy Reviews. 2008; 12: 1789-1821.

5. Duku B. Comprehensive review of biomass resources and biofuels potential in Ghana. Renewable and Sustainable Energy Review. 2009; 15: 404-415. Ref.: https://tinyurl.com/ybmnfds3

6. Singh A, Sai Gu. Biomass conversion to energy in India: a critique. Renewable and Sustainable Energy Review. 2008; 14: 1367-1378. Ref.: https://tinyurl.com/ybvhmwbn

7. Sims RH. Not too late: IPCC identifies renewable energy as a key measure to limit climate change. Renewable Energy World. 2007; 10: 31-39.

8. Hood AH. Energy from nonwoody biomass in the Sudan. Energy Research Institute (ERI). Khartoum: Sudan. 1994.

9. National Energy Administration (NEA). Renewable energy assessment for the Sudan. Khartoum: Sudan. 1982.

10. National Energy Administration (NEA). A pre-investment study for fuel production from agricultural wastes for power generation and household consumption. Khartoum: Sudan. 1993.

11. Omer AM. Renewable energy potential and future prospects in Sudan. Agriculture Development in Arab World. 1996; 3: 4-13.

12. Omer AM. Sudan energy background; an overview. Renewable Energy. 1998; 14: 467-472. Ref.: https://tinyurl.com/yavmxlm9

13. Energy Research Institute (ERI). Renewable energy resource potential in Sudan. Khartoum: Sudan. 1987.

14. National Energy Administration (NEA). The national energy plan 1985-2000. Khartoum: Sudan. 1985.

15. National Energy Administration (NEA). Energy Handbook. Khartoum: Sudan. 1991.

16. Ali GE, Shommo SA. Sudan biomass energy issues and options. Energy Research Institute (ERI). Khartoum: Sudan. 1993.

17. German Agency for Technical Cooperation (GTZ). Utilisation of biomass. Khartoum: Sudan. 1985. 
18. Omer AM. Renewable energy technology applications in the Sudan. In: Proceedings of the Third World Renewable Energy Congress. Reading: UK. 1994.

19. Omer AM. Biogas technology and the environment. Regional Energy News. 1996; 2: 2-5.

20. Ali GE, Huff CH. Canun El Duga, Improved charcoal stoves for the Sudan. Khartoum: Sudan. 1984.

21. D'Apote SL. IEA biomass energy analysis and projections. In: Proceedings of Biomass Energy Conference: Data, analysis and Trends, 23-24 March, Paris: OECD. 1998.

22. The World Bank. World development Report 2000/2001. Oxford: Oxford University Press. 2001.

23. FAO. State of the world's forest. Rome: FAO. 1999.

24. National Forestry Administration (NFA). Forestry Handbook. Khartoum: Sudan. 1994.

25. Haripriye G. Estimation of biomass in India forests. Biomass and Bioenergy. 2000; 19: 245-258. Ref.: https://tinyurl.com/ybxk9hwq

26. Hall 0 , Scrase J. Will biomass be the environmentally friendly fuel of the future? Biomass and Bioenergy. 1998; 15: 357-367. Ref.: https://tinyurl.com/y88c6953

27. World Bank. Sudan. 2010. Ref.: https://tinyurl.com/32wtcqw

28. Yongabi KA, Harris PL, Sambo AS, Agho MO. Managing cow dung with a cheap, low tech plastic digester. Proceedings of the 29 WEDC International Conference on Water and Environmental Sanitation co-organised by Water Engineering Development Centre of Loughborough University, UK, in conjunction with the Ministry of water resources, Abuja holding at Abuja. 2003; 74-77. Ref.: https://tinyurl.com/y6jk6j74

29. Agbor VB, Cicek N, Sparling R, Berlin A, Levin DB. Biomass pretreatment: Fundamentals toward application. Biotechnology Advances. 2011; 29: 675-685. Ref.: https://tinyurl.com/y58d29wc

30. Kucharska K, Hołowacz I, Konopacka-tyskawa D, Rybarczyk P, Kamiński M. Key issues in modeling and optimization of Lignocellulosic biomass fermentative conversion to gaseous biofuels. Renewable Energy. 2018; 129: 384-408. Ref.: https://tinyurl.com/y92vzs5m

31. Teixeira RSS, Silva AS, Moutta RO, Ferreira-Leitão VS, Barros RRO, et al. Biomass pretreatment: a critical choice for biomass utilization via biotechnological routes. BMC Proc. 2014; 8(Suppl 4): 034. Ref.: https://tinyurl.com/y76d73pm 